\title{
Design and validation of an instrument to statistically measure business growth
}

\section{Diseño y validación de un instrumento que permita medir estadísticamente el crecimiento empresarial}

\author{
LANDAZURI-AGUILERA, Yara $\dagger^{*} \&$ ACOSTA-MELLADO, Erika
}

Instituto Tecnológico de Sonora

ID $1^{\text {st }}$ Author: Yara, Landazuri-Aguilera / ORC ID: 0000-0002-7784-2762, Researcher ID Thomson: S-6759-2018, CVU CONACYT ID: 625073

ID $1^{\text {st }}$ Coauthor: Erika Ivett, Acosta-Mellado / ORC ID: 0000-0003-3526-8923, Researcher ID Thomson: X-8807-2019, CVU CONACYT ID 282641

DOI: 10.35429/JEDT.2020.7.4.8.16 Received September 10, 2020; Accepted December 20, 2020

\begin{abstract}
The objective of this research is to design a questionnaire that allows measuring business growth in micro and small companies. The instrument was applied to 65 small and medium-sized companies through the analysis of the information collected, the main characteristics of the companies under study were determined and the growth factors that can be measured and evaluated and that are linked to the Business Growth. For this research the variables considered are the financial factor; measured by income, costs, profitability and investment, the technological factor; measured by adopting technology and updating systems, the competition factor; relationship with the environment, growth planning and competition in the market, the human resource factor measured by the specialization of human resources and growth of key employees, finally business growth, was measured through the number of employees, total assets and sales. The questionnaire was measured using a Likert-type scale with 5 response options. The hypothesis that this research is intended to test is that financial, technological, competition and human resource factors influence business growth. The research results show that the instrument is reliable according to the results of the pilot test, the constructs are statistically significant and therefore it is valid to test the hypothesis.
\end{abstract}

Business growth, Validation, Small and medium enterprises
Resumen

El objetivo de esta investigación es diseñar un cuestionario que permita medir el crecimiento empresarial en las micro y pequeñas empresas. El instrumento se aplicó a 65 empresas Pequeñas y Medianas empresas por medio del análisis de la información recolectada, se determinaron las principales características de las empresas objeto de estudio y se establecieron los factores de crecimiento que pueden ser medidos y evaluados y que se encuentran vinculados al crecimiento empresarial. Para esta investigación las variables consideradas son el factor financiero; medido por los ingresos, costos, rentabilidad e inversión, el factor tecnológico; medido por adopción de tecnología y actualización de sistemas, el factor competencia; relación con el entorno, planeación de crecimiento y competencia en el mercado, el factor recurso humano medido por la especialización del recurso humano y crecimiento de empleados clave, por último el crecimiento empresarial, se midió a través del número de empleados, activos totales y ventas. La medición del cuestionario fue a través de una escala de tipo Likert con 5 opciones de respuesta. La hipótesis que se pretende comprobar con esta investigación es que los factores financieros, tecnológicos, competencia y recurso humano influyen en el crecimiento empresarial. Los resultados de la investigación demuestran que el instrumento es confiable de acuerdo con los resultados de la prueba piloto, los constructos son estadísticamente significativos y por lo tanto es válido para comprobar la hipótesis.

Crecimiento empresarial, Validación, Pequeñas y medianas empresas

Citation: LANDAZURI-AGUILERA, Yara \& ACOSTA-MELLADO, Erika. Design and validation of an instrument to statistically measure business growth. Journal-Economic Development Technological Chance and Growth. 2020. 4-7: 8-16

$\dagger$ Researcher contributing first author. 


\section{Introducction}

The relevance of Micro, Small and Medium Enterprises (MSMEs) in terms of growth is unquestionable, both for the activities they carry out and for their contribution to job creation and, without a doubt, for their participation in development socioeconomic status of the areas where they are located. Okpara \& Wynn (2007) affirm that MSMEs are considered as drivers in the generation of employment, economic growth and allies in the fight against poverty in developing countries. In the economic environment, it is considered that when a micro or small business entrepreneur prospers, it generates new jobs by demanding labor, therefore its sales tend to increase, and with this it achieves higher income, which contributes to the generation of gross domestic product (Okpara \& Wynn, 2007).

Despite the great importance of MSMEs in the economy of any region, it is difficult to monitor their growth due to the lack of monitoring by governments and / or associations as a result of the very specific characteristics that distinguish them. Similarly, it is not possible to carry out some type of comparative analysis among the Latin American countries because they do not have homogeneous indicators (Guaipatín, 2003).

It is unquestionable that MSMEs around the world face a series of obstacles that reduce their development and long-term validity. Previous studies indicate that in developing countries the mortality rate of small businesses is higher than in developed countries (Arinaitwe, 2006). In addition, to survive, companies must develop specific short and long-term strategies because for a new company the level of risk and its probability of lasting more than five years are low (Sauser, 2005).

In Mexico, business growth is a topic on the public agenda since $97.6 \%$ of the companies are micro-sized and occupy $75.4 \%$ of the economically active population; $2 \%$ are small in size and $0.4 \%$ are medium in size. The latter employ $13.5 \%$ and $11.1 \%$ respectively of the total employed personnel. According to data from the National Survey on Productivity and Competitiveness of Micro, Small and Medium Enterprises (ENAPROCE, 2015).
According to the above, the study of micro and small companies in Mexico is relevant to identify proven strategies that allow entrepreneurs to make decisions focused on the growth and consolidation of their businesses.

The results of the National Survey on Productivity and Competitiveness of micro, small and medium-sized enterprises in Mexico, show that in the case of micro-enterprises $66 \%$ do not provide training, justifying that the staff has the knowledge and skills to develop their work Associated with this, more than $40 \%$ of companies attribute their lack of growth to competition from informal companies and lack of credit, also $74.5 \%$ of companies do not use computer equipment as a work tool (ENAPROCE, 2015) .

For their part, small companies indicate that their growth is inhibited due to the numerous procedures and high taxes, only 2 out of 100 companies participate in value chains and $93.4 \%$ of companies use computer equipment as a work tool and $92.4 \%$ use the internet as part of their daily operations (ENAPROCE, 2015). These figures show the need to identify the factors that intervene in the growth of Mexican micro and small companies, the above is a reference to focus the problem through factors such as finances, the use of technology, recognition of the competition and human resources.

In this sense, the objective of this research is to design an instrument that allows to statistically measure the business growth of micro and small companies through financial, technological, competition and human resource factors.

\section{Literature review}

According to Fernández, García and Ventura (1988), business growth allows a company to be able to compare its level of competitiveness in the market, in order to determine a reference point around which the policies that make up competitive strategies will be established. . For companies to prosper, they must make decisions that allow them to identify, maintain and expand their space in the market. 
Blázquez, Dorta and Verona (2006) define the following: Business growth can be understood as the process of adaptation to changes required by the environment or promoted by the entrepreneurial spirit of the manager, according to which, the company is compelled to develop or expand its productive capacity by adjusting or acquiring new resources, making organizational changes to support the modifications made; All of which must be endorsed by the financial capacity of the company that allows, through this process, to obtain lasting competitiveness over time (p. 187).

Internal and external factors influence business growth (Blázquez, Dorta \& Verona, 2006). They also confirm that total assets, number of employees, volume of sales, net investment, market value and equity are the variables that measure business growth. Within the internal factors, reference is made to the age and size of the company, the motivation, the ownership structure, the knowledge management, and within the external factors, its classification is subdivided into external factors related to the sectorial environment and external factors of higher level or macro environment; the first includes competitors, customers and suppliers, and the second includes demand, technological advances, accessibility to private credit and government support.

For Canals (2000) the final objective of organizations is not growth, this is considered a means to achieve other objectives and the prolonged absence of growth can be an indicator of failure; therefore growth is important, not only for the possible impact on the value of the company, but for a set of more subtle reasons that can guarantee the survival of an organization in the medium term such as: the attraction of professional talent, the need to attract financial resources, the risk of substitution and the risk of imitation, the overcoming of the mature sector mentality and the concern for the future, for the way to face it.

On the other hand, Amat and Lloret (2014) argue that factors such as leadership, business culture, business model, income, costs, investments and financing explain business growth.
Accordingly, Rupasingha and Wang (2017) study access to capital in the growth of small businesses in the United States in a panel of 3,050 counties during the period 1996-2010, and find that loans granted under the Reinvestment Law Community have a statistically significant positive effect on the growth of the small businesses in the study.

Financing is a factor that determines the growth of companies (Rubio and Aragón, 2005). Therefore, one of the factors most used to measure the growth of companies is sales income and access to financing, production costs and suppliers, another important factor is the number of employees or market share, (García and Romero, 2010).

Various studies show that Information and Communication Technologies (ICT) are used as a facilitating agent for the socioeconomic consolidation of MSMEs, being included in the development agendas of several countries (Caldeira and Ward, 2002) and corroborating the contributions of Porter (2001), where he points out the competitive advantages that ICT can generate for the benefit of the business.

Shin (2007) refers to ICT as a strategic resource that supports companies to find new opportunities in the market, with low costs and high probability of success. However, there are studies that show how in some organizations the adoption of ICTs has generated barriers and obstacles that make their implementation difficult (Modimogale and Kroeze, 2009, MacGregor, Vrazalic, Carlsson, Bunker \& Magnusson, 2002).

In a study carried out with 400 MSMEs from Aguascalientes (Mexico), they evidence the positive influence on the use of technology, as well as the factors recognized in the 4 performance models proposed by Quinn and Rohrbaugh (1983), especially in the rational model; Likewise, they confirm a positive impact on the general performance of companies (Maldonado et al., 2010).

In the literature, different methodologies and tools have been identified to try to measure the performance generated by companies, either through the study of finances, the operations of the sector and efficiency in the use of resources, up to now 
There is no method with respect to a generalizable indicator to measure growth, some are objective, by extracting data from financial indicators, while others are subjective, since they are obtained by exploring the perception or points of view of actors involved in the processes of the company and, in some cases, external observers. (Estrada and Sánchez, 2009).

The search by companies to preserve or increase their competitive position with respect to their competitors encourages the search for models that promote growth as a strategy to achieve the position desired by the entrepreneur; in the same way, business growth is considered as part of a business strategy, since this concept comes to express "the link between the company and its environment" (Grant, 1995, p. 57).

In this sense, Bozbura (2007) considers that SMEs that invest more economic resources in training to increase the capacities of employees, experience and knowledge, are investing in the most important asset for any organization, because it is precisely human capital that generates new knowledge (Ulrich, 1997).

The measurement of business growth continues to be subjective, due to the use and interpretation of non-quantitative indicators that differ depending on the aspect that is being analyzed, such as human capital, operations, technology, among others. The accounting results do not indicate that a company is capable of sustaining its current results over time and generating profitable business in the future; Therefore, it is necessary to analyze organizational performance from a broader perspective that allows considering the risks inherent to the activity that these companies carry out (Dobbs and Koller, 2006).

Together, the prosperity of an organization is attributed to the relationship between the knowledge generated by human capital in the organization and learning, understanding that learning is a process through which the individual within an organization improves their practices avoiding repeating mistakes past, hence the literature finds a correspondence between the transformation of knowledge of human capital with the success of learning in the organization (Sharma, Siddiqui, Sharma, Sing, Kumar, Kaushal and Banerjee, 2007).
The growth model based on the theory of resources and capabilities, focuses precisely on the existence of the resources that the company has at a given time and that these have the ability to be used by the organization through the development of skills distinctive, where, without a doubt, the entrepreneurial attitude of the businessman or manager plays a key role in inducing growth.

These arguments allow proposing the following research hypothesis:

Hi: Financial, technological, competition and human resource factors influence business growth.

\section{Methodology}

The research was supported by the inductive method, which allowed from the study of a set of micro and small companies in Ciudad Obregón Sonora supported by the literature theory, starting from the variables that make up each of the factors.

To carry out the verification of the hypothesis raised in this research, the following methodology is defined. This research is exploratory, among the purposes of this type of research is to indicate the possibility of specifying a problem, to extract data and terms that allow generating the triggering questions of the research with the aim of designing an instrument to statistically measure the factors internal and external that intervene in the business growth of micro and small companies.

The instrument that will serve to identify whether financial, technological, competition and human resource factors influence business growth. The questionnaire is designed initially by a list of seven items for each factor, with the intention of measuring the following in each of them:

a. Financial factor: it will collect evidence on bank loans, supplier credit, inventory control, cost control, government support, and reinvestment of profits. 
b. Technological factor: you will obtain information on specialized software for the operation of the company, the use of the bank terminal, the use of company web pages, social networks to attract clients and identity emails.

c. Competition factor: it will extract information about differentiated products, the assessment to detect customer needs, the identification of advantages to compete, expansion possibilities, competition strategies.

d. Human resource factor: it will verify if the employee receives training, if the company recognizes the key employee, the job identity, the involvement of the staff in the company's goals, the specialization of the position and the recognition of the employees to improve their work.

The first section contains 5 general information questions to characterize the companies. The second section includes the internal and external factors that affect business growth through items related to the independent variables: the financial dimension, the technological dimension, the competitive environment dimension and the human resource dimension. The third section corresponds to the dependent variable, business growth, which will be measured through growth indicators such as: number of employees, total assets and sales.

To measure business growth there are different theories that seek to explain the reasons why companies tend to grow and endure over time. The theory of the firm is explained based on the maximization of profits, the obtaining of economies of scale and the development of the company within a market. From the economic perspective, growth is considered through increased sales and consequently through performance with a decrease in risk and higher market value (Portocarrero \& Byrne, 2003). From the sociological point of view, growth originates to increase the prestige of company managers, to generate new jobs or to improve the status of the organization (Goleman, 2018).
Therefore, growth is an index of the economic activity of a company, which can be measured by determining indicators such as sales, job creation, increase in assets and growth compared to competitors (García, Toro \& Sánchez, 2013). For the purposes of this investigation, it has been determined that this will be measured through the increase in sales, total assets and number of new employees. Finally, for this research, at first the measurement scales used in previous studies were reviewed. Appropriate metric referents were selected, adapted to the context, and others that had not been previously generated were built, such as technology, competence and human resources.

Finally, the scale to measure the Factors that influence the business growth of micro and small businesses was a 7-item scale for financial, technological, competition and human resource factors. All were measured using a 5-point Likert-type scale with $1=$ Total disagreement to $5=$ Total agreement as limits.

For its part, the growth variable will be measured with five items of which three of them are evaluated with a range from "never" to "always" because the literature tests the effect that variables such as size and economic sector have on you. Business Growth; therefore, items were included that will offer descriptive and valuable information on these variables.

\section{Pilot test}

As part of the preliminary results of the pilot test of the questionnaire applied to the companies under study, emphasis is placed on the unit of analysis, the study subjects are the micro and small companies in southern Sonora of the commercial sector, because this sector is made up of a little more than $55.5 \%$ of the population.

The sampling method was nonprobabilistic, through personalized interviews with the managers, owners or managers of the companies, the majority of the companies surveyed are small companies, where $43 \%$ have an antiquity of more than 20 years. $53 \%$ of those interviewed are female and $69 \%$ of these do not belong to any chamber or group. For the pilot test, 65 data were recorded, therefore, as the observations increase, it is expected that the results may vary. 


\begin{tabular}{|l|l|l|}
\hline \multicolumn{1}{|c}{ Concepto } & \multicolumn{1}{c}{ Clasificación } & \multicolumn{1}{c|}{$\%$} \\
\hline \multirow{4}{*}{$\begin{array}{l}\text { Level of studies of the } \\
\text { interviewee }\end{array}$} & high school & $14 \%$ \\
\cline { 2 - 3 } & Technical career & $16 \%$ \\
\cline { 2 - 3 } & Bachelor's degree & $56 \%$ \\
\cline { 2 - 3 } & Specialty & $6 \%$ \\
\cline { 2 - 3 } & Postgraduate & $8 \%$ \\
\hline \multirow{4}{*}{ Sex } & Female & $53 \%$ \\
\cline { 2 - 3 } & Male & $47 \%$ \\
\hline Company age (years) & 0 to 5 & $12 \%$ \\
\cline { 2 - 3 } & 6 to 10 & $20 \%$ \\
\cline { 2 - 3 } & 11 to 20 & $25 \%$ \\
\cline { 2 - 3 } & More than 20 & $43 \%$ \\
\hline
\end{tabular}

Table 1 Characteristics of the sample Source: Own Elaboration (2019)

Findings in the application of the instrument

The questionnaire was applied to 68 companies in the population in three periods, the first from October to November 2018, where 28 questionnaires were obtained, then from January to March 2019, reaching 40 complete questionnaires, after the elimination of three due to missing data, obtaining 65 complete and valid questionnaires for the analysis.

\section{Results}

For this research, the determination of reliability was carried out through Cronbach's alpha, supported by the SPSS statistical tool, version 21 , the objective is to verify that most of the items designed for each variable allow reaching alphas with acceptable values, that is, higher than 0.650, considered as the minimum acceptable for scientific research, according to Sánchez and Gómez (1998) and Cervantes (2005).

Table 2 describes the objectives to be evaluated in the items that are considered the proposed instrument to measure business growth in this research. These items will be subject to evaluation to determine the reliability of the instrument and, if necessary, those in which the factor loadings are below the statistically acceptable results in the literature will be eliminated.

\begin{tabular}{|c|c|c|}
\hline Factor & Item & objective \\
\hline \multirow[t]{6}{*}{ Financial } & $\begin{array}{l}\text { F1 and } \\
\text { F2 }\end{array}$ & Evaluate financial results \\
\hline & F3 & Assess diversification \\
\hline & F4 & Assess liquidity \\
\hline & F5 & Lower costs \\
\hline & F6 & Reinvesting profits \\
\hline & F7 & Invest of total assets \\
\hline \multirow[t]{5}{*}{ Technological } & $\mathrm{T} 8$ & $\begin{array}{l}\text { Evaluate the } \\
\text { implementation of } \\
\text { specialized software }\end{array}$ \\
\hline & $\begin{array}{l}\text { T9 and } \\
\text { T10 }\end{array}$ & $\begin{array}{l}\text { Evaluate the use of } \\
\text { technological tools }\end{array}$ \\
\hline & T11 & $\begin{array}{l}\text { Evaluate the investment } \\
\text { and use of the website }\end{array}$ \\
\hline & $\mathrm{T} 12$ & $\begin{array}{l}\text { Assess investment in } \\
\text { technology and social } \\
\text { media }\end{array}$ \\
\hline & $\begin{array}{l}\text { T13 } \\
\text { and } \\
\text { T14 }\end{array}$ & $\begin{array}{l}\text { Evaluate customer service } \\
\text { through the use of } \\
\text { technology }\end{array}$ \\
\hline \multirow[t]{6}{*}{ Competition } & $\mathrm{C} 15$ & $\begin{array}{l}\text { Analyze collaboration } \\
\text { with suppliers }\end{array}$ \\
\hline & $\mathrm{C} 16$ & $\begin{array}{ll}\text { Analyze } & \text { service } \\
\text { satisfaction } & \end{array}$ \\
\hline & $\begin{array}{l}\mathrm{C} 17 \\
\text { and } \\
\mathrm{C} 18\end{array}$ & $\begin{array}{l}\text { Evaluate } \quad \text { service } \\
\text { improvement actions }\end{array}$ \\
\hline & C19 & $\begin{array}{ll}\begin{array}{l}\text { Evaluate } \\
\text { differentiation of the } \\
\text { product / service }\end{array} & \begin{array}{l}\text { the } \\
\text { product }\end{array} \\
\end{array}$ \\
\hline & $\mathrm{C} 20$ & $\begin{array}{l}\text { Know product conditions } \\
\text { in the local market }\end{array}$ \\
\hline & $\mathrm{C} 221$ & $\begin{array}{ll}\text { Customer } & \text { retention } \\
\text { strategies } & \end{array}$ \\
\hline \multirow{6}{*}{$\begin{array}{l}\text { Human } \\
\text { resource }\end{array}$} & RH22 & Evaluate information flow \\
\hline & RH23 & $\begin{array}{l}\begin{array}{l}\text { Evaluate training } \\
\text { skills management }\end{array} \\
\end{array}$ \\
\hline & RH24 & $\begin{array}{l}\text { Recognize the company's } \\
\text { key man }\end{array}$ \\
\hline & RH25 & $\begin{array}{l}\text { Evaluate the } \\
\text { organizational climate }\end{array}$ \\
\hline & $\begin{array}{l}\text { RH26 } \\
\text { and } 27\end{array}$ & $\begin{array}{l}\text { Analyze internal } \\
\text { collaborative conditions }\end{array}$ \\
\hline & RH28 & Evaluate work identity \\
\hline
\end{tabular}

Table 2 Objectives to be evaluated in the instrument Source: Own Elaboration (2019)

The internal consistency method based on Cronbach's Alpha allows estimating the reliability of a measuring instrument through a set of items that are expected to measure the same construct or theoretical dimension. The reliability measure using Cronbach's alpha assumes that the items measure the same construct and that they are highly correlated. 
Table 2 shows the results obtained from Cronbach's alpha, the factor loadings and the significance of each factor, where it is observed that there is moderate internal consistency of the constructs, because the value of Cronbach's alpha is in the range of acceptable values. (Nunnally and Bernstein, 1994), the size of all the standardized factorial loads of the variables are significant $(\mathrm{p}<0.001)$, $(\mathrm{p}<0.005)$ and higher than 0.650 (Bagozzi and Yi, 1988), which provides evidence of reliability of the theoretical model and justifies the internal reliability of the scales (Nunally and Bernstein, 1994; Hair et al., 1995).

\begin{tabular}{|l|r|r|r|}
\hline \multicolumn{1}{|c|}{ Factor } & \multicolumn{1}{c}{ Cronbach's alpha } & \multicolumn{1}{c|}{ F } & Sig \\
\hline Financial & .665 & 20.831 & .000 \\
\hline Technological & .693 & 9.291 & .000 \\
\hline Competition & .784 & 5.392 & .000 \\
\hline Human resource & .816 & 2.627 & .035 \\
\hline Increase & .677 & 2.762 & .043 \\
\hline
\end{tabular}

Table 3 Internal consistency and convergent validity of the theoretical model

Source: Own Elaboration (2019)

It is important to point out in order to carry out the validity test and achieve the best Cronbach alpha values from the pilot test, it was necessary to eliminate some items in each factor, with the intention of increasing the loads for each construct as well as its validity. This procedure is known as content validity.

The items eliminated for each factor were. Financial factor F1 and F5, technology T12 and T14, human resources RH22, RH 23 and growth CE1, once these items have been eliminated, the results of the Cronbach alphas for the variables are acceptable according to the theory, values higher than 0.650 and lower at 0.90, are considered acceptable values for scientific research in the field of social sciences, according to Sánchez and Gómez (1998) and Cervantes (2005), the items that make up the questionnaire are not correlated and are independent.

\begin{tabular}{|l|c|}
\hline \multicolumn{1}{|c|}{ Factor } & Increase \\
\hline Financial & 1.583 \\
\hline Technological & 1.644 \\
\hline Competition & 1.790 \\
\hline Human resource & 1.402 \\
\hline
\end{tabular}

Table 4 Collinearity statistics Source: Own Elaboration (2019)
For some researchers, it is recommended that the diagnosis of collinearity between constructs or formative dimensions be less than 3.5, which would indicate the absence of multicollinearity (Petter, Straub \& Rai, 2007), other works consider acceptable VIF values lower than 5, for This research results are less than 2, which leads to confirm the absence of multicollinearity.

According to the statistical results obtained from the proposed instrument to determine the factors that influence the business growth of micro and small businesses, it was found that the instrument is statistically valid as it did not find a correlation between the independent variables and the absence of multicollinearity, therefore It can be used to measure financial, technological, competition and human resource factors, and to be able to identify the existence of a significant relationship between these factors and business growth.

\section{Conclusions}

From the results of the investigation, the following can be deduced; The factors proposed to measure business growth (financial, technological, competition and human resources) are valid to measure business growth, likewise, the proposed questionnaire is reliable and valid to assess the growth of micro and small businesses in the commercial sector .

As part of the conclusions, it can be established that the proposed objective was fulfilled, which was to design and validate an instrument that allows statistically measuring the business growth of micro and small companies through financial, technological, competition and human resource factors.

The results obtained from Cronbach's alpha, factor loadings, significance and multicollinearity of each factor are statistically acceptable, according to the theory. The content validity of the instrument is greater than 0.60 , thus meeting the acceptance and statistical validity criteria. 
The hypothesis subject to verification for this research is statistically verified for the four factors (financial, technological, competition and human resources), the results show asymptotic significance. The significance level of 0.05 verifies the rejection of the null hypothesis by accepting the hypothesis that financial, technological, competition and human resource factors influence business growth.

This study's main contribution is the design of a methodology for the development of an empirical study that will serve as input for the data collection and can be replicated in different scenarios and productive sectors in order to have the most accurate possible outlook on growth. that micro and small companies are having, as well as the dimensions with the greatest impact on business growth.

The complexity of carrying out research on micro and small companies is complex due to the diversity of sectors that these companies cover, in addition to the level of maturity between them, it is difficult to make a comparison even in companies of the same sector and size. The owner or leader of the company is the one who sets the rules of the game, who we call the man orchestra, and the maturity and management of these companies depends largely on that.

For future research, it is convenient to consider the possibility of conducting a longitudinal study that allows monitoring the growth of a significant number of companies in the commercial sector and making conclusions about the findings identified in the research period, and being able to identify sub-items of these companies according to the level of maturity and managed structure.

It is also possible to transfer this study to small and medium-sized companies that are companies with a better structure and that are also an important engine of the economy in this country and to be able to identify the growth factors in it.

\section{References}

Amat, O., \& Lloret, P. (2014). Avanzando.

Arinaitwe, S. K. (2006). Factors constraining the growth and survival of small scale businesses. A developing countries analysis. Journal of American Academy of Business, Cambridge, 8(2), 167-178.

Bagozzi, R. P., \& Yi, Y. (1988). On the evaluation of structural equation models. Journal of the academy of marketing science, 16(1), 7494.

Blázquez Santana, F., Dorta Velázquez, J. A., \& Verona Martel, M. C. (2006). Factores del crecimiento empresarial. Especial referencia a las pequeñas y medianas empresas. INNOVAR. Revista de Ciencias Administrativas y Sociales, 16(28).

Bozbura, F. (2007). Knowledge management practices in Turkish SMEs. Journal of Enterprise Information Management, 20(2), 209-221.

Caldeira, M. M., \& Ward, J. M. (2002). Understanding the successful adoption and use of IS/IT in SMEs: an explanation from Portuguese manufacturing industries. Information Systems Journal, 12(2), 121-152.

Canals, J. (2000). La gestión del crecimiento de la empresa. McGraw-Hill.

Cervantes, V. H. (2005). Interpretaciones del coeficiente alpha de Cronbach. Avances en medición, 3(1), 9-28.

Dobbs \& Koller, (2006).La medición del rendimiento a largo plazo. Harvard-Deusto Finanzas y Contabilidad, 69 (2006), pp. 4-12

ENAPROCE. 2015. Difusión de la encuesta nacional sobre productividad y competitividad de las Micro, Pequeñas y Medianas empresas. Obtenido de www.inegi.org.mx/saladeprensa/boleti nes/2016/especiales/especiale s2016 - 0 -02.pdf

Estrada Bárcenas, R., García Pérez de Lema, D., \& Sánchez Trejo, V. G. (2009). Factores determinantes del éxito competitivo en la Pyme: Estudio Empírico en México. Revista Venezolana de Gerencia, 14(46), 169-182. 
García, A. I. F., Rodríguez, R. G., \& Victoria, J. V. (1988). Análisis del crecimiento sostenible por los distintos sectores empresariales. Documentos de trabajo (Universidad de Oviedo. Facultad de Ciencias Económicas), (3), 3-26.

García, M. L. S., Toro, S. M., \& Sánchez, B. T. (2013). Determinación de la competitividad de la PYME en el nivel micro: El caso de del Distrito Federal, México. FAEDPYME International Review-FIR, 2(4), 18-32.

Gibrat, R. (1931). Les inégalits économiques. Sirey.

Grant, R. M. (1995). Contemporary strategy analysis: Concepts. Technique, and Applications, Massachusetts: Balckwell.

Goleman, D. (2018). Inteligencia emocional en la empresa (Imprescindibles). Conecta.

Guaipatín, C. (2003). Observatorio MIPYME: Compilación estadística para 12 países de la Región. Inter-American Development Bank.

Hair, J.F. Jr, Anderson, R.E., Tatham, R.L. \& Black, W.C. (1995) Multivariate Data Analysis with Readings. Prentice Hall International Editions, Englewood Cliffs, NJ.

MacGregor, R., Vrazalic, L., Carlsson, S., Bunker, D., \& Magnusson, M. (2002). The impact of business size and business type on small business investment in electronic commerce: a study of swedish small businesses. Australasian Journal of Information Systems, 9(2).

Maldonado, G., Martínez, M., García, D., Aguilera, L., González, M. (2010). La influencia de las TICs en el rendimiento de la PyME de Aguascalientes.Investigación y Ciencia, 18 (47), 57-65.

Modimogale, L., \& Kroeze, J. H. (2009). Using ICTs to become a competitive SME in South Africa.

Nunnally, J. C., \& Bernstein, I. H. (1994). Validity. Psychometric theory, 3, 99-132.

Okpara, J. O., \& Wynn, P. (2007). Determinants of small business growth constraints in a subSaharan African economy. SAM advanced management journal, 72(2), 24.
Petter, S., Straub, D. W., \& Rai, A. (2007). Specifying formative constructs in information systems research.

Portocarrero, F., \& Byrne, G. (2003). Estructura de mercado y competencia en el microcrédito. Lima: CIES.

Quinn, R. E., \& Rohrbaugh, J. (1983). A spatial model of effectiveness criteria: Towards a competing values approach to organizational analysis. Management science, 29(3), 363-377.

Rubio, A., \& Aragón, A. (2005). Factores explicativos del éxito competitivo. E-Journal, 1(216), 35-69.

Rupasingha, A., \& Wang, K. (2017). Access to capital and small business growth: evidence from CRA loans data. The Annals of Regional Science, 59(1), 15-41.

Sánchez Pedraza, R., \& Gómez Restrepo, C. (1998). Conceptos básicos sobre validación de escalas. Rev. colomb. psiquiatr, 27(2), 121-130.

Sauser, W. I., Jr. (2005). Starting Your Own Business? Prepare for Success. SAM Management in Practice, 3(1), 1-4.

Sharma, R. S., Siddiqui, A., Sharma, A., Singh, R., Kumar, R., Kaushal, S., \& Banerjee, S. (2007). Leveraging knowledge management for growth: a case study of Tata consultancy services. Journal of Information Technology Case and Application Research, 9(4), 29-65.

Shin, N. (2010). Information technology and diversification: How their relationship affects firm performance. In Strategic Information Systems: Concepts, Methodologies, Tools, and Applications (pp. 2460-2474). IGI Global.

Ulrich, D. (1997). Recursos humanos champions. Ediciones Granica SA. 